\title{
우리의 언타이드 원조 추진과 국제 원조조달시장 참여 방안
}

박 강 호 / 외교통상부 개발협력정책관

\section{I. 머리말}

1997 년 이후 국제 개발원조 규모는 지속적으로 확 대되어 왔으며 이러한 추세는 지속될 전망이다. 이 러한 원조 규모 확대와 더불어, 2005 년 원조 효과 성에 대한 파리선언이 상징적으로 보여주고 있듯 이 원조 효과성을 증대시키기 위한 국제사회의 노 력도 강화되고 있다. 개발원조의 양적 증대뿐만이 아니라 질적 개선도 함께 이루어지고 있는 것이다. 2001년 OECD 개발원조위윈회(DAC)의 최빈국 원 조 언타이드 권고안 이후 지속적인 언타이드 원조 확대 노력도 이러한 원조 효과성 증진을 위한 국제 적 흐름의 맥락에서 파악할 수 있다.

우리나라 역시 국제사회에서 주목받고 있는 신흥 공여국으로서 원조의 양적 증대뿐만이 아니라 질 적 개선을 위한 노력을 지속하고 있다. 2010년 $\mathrm{OECD}-\mathrm{DAC}$ 가입을 추진하고 있으며, 이에 따라
국제적 기준에 부합하는 개발원조 제공을 위한 원 조정책 및 제도 개선을 진행하고 있다. 특히 우리 의 원조 언타이드화율은 2005 년 $2.6 \%$ 로 DAC 회 원국 평균 $94.5 \%$ (2006년)에 비해 크게 미흡하여 시급한 개선이 요구된다. 언타이드 원조의 실시를 통해 조달비용을 낮추어 원조자금의 효과적 집행 을 도모하고, 현지조달시스템 활용을 통해 수원국 의 개발전략에 부합하는 원조 이행을 실시하고 수 원국의 개발 능력 배양에 기여하기 위해 노력해야 하는 것이다.

이러한 원조 언타이드화는 그 자체가 목적이 아니 고, 궁극적인 목적은원조 효과성 증대라는 점에 주 목하여 우리나라 실정에 맞추어 추진해야 한다. 원 조 언타이드화 추진의 필요성에 대한 광범위한 합 의에도 불구하고, 언타이드 원조 확대에 국내정치 적 어려움이 있는 것이 사실이다. 충분한 경쟁력이 갖추어지지 않은 상황에서 언타이드 원조 확대는 
우리 기업의 수주기회 축소로 이어질 수 있고, 선 진국들의 선점으로 인해 사실상 타이드화 되어 있 는 국제 원조조달시장에의 접근도 쉽지 않기 때문 이다. 즉, 언타이드 원조 확대를 위해서는 우리 기 업들의 경쟁력 및 국내 컨설턴트의 역량 강화를 위 한 합리적 보완책이 전제되어야 하는 것이다.

따라서 본고는 국제사회의 언타이드 원조 동향 및 우리나라의 추진 현황을 간략히 검토하고, 이를 토 대로 우리의 언타이드 추진 방안을 제시하고자 한 다. 아울러 언타이드 원조 확대로 인한 다양한 영향 에 대한 제도적 보완장치 마련을 위해, 국제 원조조 달시장의 현황 및 우리나라의 진출 현황과 문제점 분석을 통해 우리 기업의 수주 경쟁력 강화와 국내 개발 컨설턴트 육성 방안을 모색해 보고자 한다.

\section{II. 국제사회의 언타이드 원조 동향 및 우리나라의 추진 현황}

\section{1. 언타이드 원조에 대한 국제사회의 논의와 추진 현황}

\section{가. DAC의 최빈국 원조 언타이드 권고안과 파리선언}

일반적으로 언타이드(untied) 원조란 수원국이 조 달하는 수입물자, 용역의 조달처를 공여국 또는 일 부 소수국가로 한정하지 않는 경우를 의미한다. 그
런데 실제로 공여국 입장에서는 조달의 용도, 물 자, 교역의 품목, 사양, 규격 등을 제한하거나 조달 처가 되는 국가나 지역을 제한하는 타이드 원조를 통해 단기적으로 자국의 수출 및 고용증진을 도모 해 온 경우가 많다.

타이드 원조는 공여국 중심의 원조로 수원국의 주인 의식(ownership)을 저해하며, 원조산업 입찰시 제 한 경쟁으로 높은 비용을 유발함으로써 원조 효과성 을 현격하게 저하시킨다. 이러한 타이드 원조의 비 효율성을 개선하기 위해 DAC는 2001년 최빈국에 대한 원조의 언타이드화를 권고하였다. 기존 권고 안은 최빈국에 대해 식량원조, 기술협력의 경우 특 정 프로젝트 준비나 수행과 무관한 독립된 기술협력 (Free-standing Technical Assistance:FTA)을 제외한 총8개 대상을 언타이드 원조대상으로 규정 하고 있다. 현재 DAC는 기타저소득국(Other Low Income Countries: OLICs) 및 고채무빈곤국 (Non-LDC HIPCs)으로 언타이드 대상국가 확대 를 추진하고 있으나 회원국들의 반대로 컨센서스 를 이루지는 못하였다. 아울러 적용대상범위의 확 대와 관련하여 기술협력(TC)의 범위를 재편하여 일부를 언타이드 범위로 포함할 것을 고려하고 있 으나 합의를 이루지 못하고 있다.

2001년 DAC 권고안과 더불어 2005년 원조 효과 성에 대한 파리선언은 수원국의 현지 원조조달시 스템 활용 및 언타이드 원조 확대를 권고하고 있 다. 파리선언의 5 개의 중점 추진과제 중 하나인 
'수원국의 개발전략에 공여국의 원조의 일치 (Alignment)' 과제는 공여국이 수원국의 정부조달 시스템을 활용할 것을 권고하고 있다. 이는 수원국 의 개발전략에 맞는 원조를 이행하고, 조달과정에 수원국의 주도적인 참여를 촉진함으로써 원조 효 과 증진을 가능하게 한다.

\section{나. 언타이드 원조의 국제적 추진 현황}

양자간 원조 언타이드 비율은 DAC 평균 2001년 79.9\%에서 2006년 94.5\%로 크게 증가하였다. 영 국, 호주, 덴마크, 아일랜드는 원조의 언타이드화 를 선언하고 $100 \%$ 언타이드 원조를 시행하고 있 다. 특히, 최빈국에 대한 원조 언타이드 권고에 대 한 반작용으로 최빈국 원조 규모가 감소할 것이라 는 우려와는 달리, 최빈국에 대한 양자간 원조 규 모는 1991 2001년 연평균 115억 달러에서 2005 년 214억 달러로 크게 증가하였고, 최빈국에 대한 양자 언타이드 비율도 1991 2001년 연평균 $0.55 \%$ 에서 2005년 $0.76 \%$ (164억 달러)로 증가하 였다.

\section{2. 우리나라의 언타이드 원조 추진 현황}

우리나라의 양자간 언타이드 원조비율은 2001년 $1.5 \%$ 에서 2005 년 $2.6 \%$ (1,110만 달러)로 증가하였 으나, DAC 회원국 평균인 $91.8 \%(2005$ 년)에 비하 면 크게 미흡한 수준이다. 2005년 기준 KOICA의 무상원조 사업중 언타이드 비율은 $15.7 \%$ 이며, 최
빈국에 대한 언타이드 비율은 $13.8 \%$ 이다. KOICA 의 무상원조 사업중 현지입찰을 통해 조달된 사업 을 제외한 대부분은 타이드 원조이다.

\section{III. 우리의 언타이드 원조 추진 방안}

\section{1. 언타이드 원조 정책의 필요성 및 영향}

\section{가. 필요성}

2001년 DAC 언타이드 권고안이 제시하고 있듯이 원조 언타이드화의 궁극적인 목적은 원조 효과성 제고에 있다. 우선, 언타이드 원조는 $\mathrm{ODA}$ 의 비용 대비 효과성(cost effectiveness)을 증가시킨다. 타이드원조의 경우, 원조사업 입찰시 공여국 기업 에게 유리한 방식으로 추진하여 높은 비용이 유발 된다. $\mathrm{DAC}$ 의 연구에 따르면 타이드 원조로 구매 되는 재화와 용역의 가격이 국제경쟁가격에 비해 $15 \sim 30 \%$ 높은 것을 알 수 있다. 따라서 언타이드 원조의 실시는 타이드 원조의 높은 비용을 절감하 는 효과가 있다. 아울러, 중장기적으로 현지조달시 스템을 활용한 원조조달이 활성화되는 경우 수원 국의 개발전략과 이익에 부합하는 원조이행으로 원조 효과성을 제고할 수 있다.

이러한 원조 효과성 제고를 위한 원조 언타이드화 추진은 이미 명확한 국제적인 흐름이다. 앞서 언급 한 바와 같이 DAC는 2001년 권고안과 2005년 파 
리선언을 통해 경쟁원칙에 입각한 원조조달과 현 지조달시스템 활용의 필요성을 명시하고 있다. 2010년 DAC 가입을 준비하고 있는 우리나라로서 는 국제사회가 요구하는 기준에 부합하는 원조 언 타이드화를 시행하여 국제사회에서 우리나라의 위 상 강화를 도모해야 한다. 타이드 원조를 지속적으 로 시행할 경우, 수원국의 빈곤퇴치 보다는 공여국 의 경제적 이익 추구를 위해 $\mathrm{ODA}$ 를 도구적으로 이용한다는 비판을 면하기 어려울 것이다.

\section{나. 원조 언타이드화가 우리나라에 미치는 경제 적 영향}

언타이드 원조 시행은 국제사회에서 우리 ODA의 위상 강화에 기여할 뿐만이 아니라 원조자금의 효 율적 집행을 가능하게 하고 우리 기업의 국제 $\mathrm{ODA}$ 조달시장 진출을 촉진하는 효과를 갖는다. 경쟁을 통해 원조조달시장에서 상품과 용역의 가 격 저하로 실질적인 원조 조달시장 규모 확대의 효 과를 기대할 수 있다. 중 - 장기적으로 이러한 경쟁 원리의 도입은 원조조달시장의 투명성을 증대시키 고 기업들의 경쟁력 강화를 촉진할 것이다. 아울러 원조 언타이드화의 실시시 $\mathrm{EU}$ 조달시장과 같이 진출이 불가능했던 국제조달시장에의 진출도 가능 해진다. $\mathrm{EU}$ 의 경우 상호주의 원칙에 기반하여 조 달시장 진입을 허용하고 있는바, 언타이드 원조 실 시시 진출가능한 원조조달시장 규모 확대를 기대 할 수 있다.
이처럼 언타이드 원조 확대로 인해 국제 $\mathrm{ODA}$ 시 장 규모가 확대됨에 따라 우리기업의 진출기회가 확대되고 있는 것은 사실이나, 경쟁력이 충분히 갖 추어져 있지 않은 상황에서 원조 언타이드화는 우 리 기업들에게 부정적 영향을 미칠 수 있다. 언타 이드화를 추진하려면 국제경쟁입찰(ICB)이나 현지 조달시스템을 이용해야 하기 때문에 경쟁력이 없 는 경우, 조달시장에서 수주기회가 축소되고 사업 관리상의 리스크 증가로 원조조달시장에의 우리 기업 참여 자체가 어려워질 수 있는 것이다.

우리나라는 프로젝트 시공에 있어서 풍부한 경험 과 실적, 조달 및 공사관리 등에 강점을 가지고 있 는 것이 사실이지만, 기본설계나 타당성 조사와 같 은 엔지니어링 분야의 경쟁력이 낮은 편이다. 실질 적으로 우리 기업의 수주율을 높이기 위해서는 기 획, 설계 중 엔지니어링 분야의 경쟁력이 높아야 하는데 우리 기술수준 및 엔지니어링 수준은 선진 국 경쟁력의 70 80\%에 불과하기 때문에 원조 언 타이드화로 인한 조달시장 개방시 수주율 저하의 우려가 있다. 따라서 언타이드화 추진은 이러한 부 정적 효과를 최소화할 수 있는 전략과 합리적 대책 마련과 함께 이루어져야 한다.

\section{2. 언타이드 원조 추진 방안}

\section{가. 단계적 · 점진적 추진}

원조 언타이드화 추진은 $\mathrm{ODA}$ 의 언타이드화로 예 
〈표 1〉〈연도별 무상원조 언타이드화 목표율〉

(단위: 백만 달러, \%)

\begin{tabular}{c|c|c|c}
\hline \hline 연도 & 국제사회동향 & 단계 구분 & 목표 언타이드율 \\
\hline 2008 & $\begin{array}{c}\text { 파리선언 중간점검 } \\
\text { (아크라 HLF) }\end{array}$ & $\begin{array}{c}\text { - 준비 및 시범단계 } \\
\text { (최빈국 대상 시범사업 실시) }\end{array}$ & $20 ~ 30 \%$ \\
\hline 2010 & DAC 가입 & - 도입단계 & $50 \%$ \\
\hline \multirow{2}{*}{2015} & MDGs 목표연도 & (최빈국 언타이드화 추진 및 일부 저소득국 선별적으로 확대) & - 활성화 단계 \\
& & (전면적 언타이드 원조 추진) & $90 \%$ \\
\hline
\end{tabular}

상되는 다양한 효과를 감안하여 단계적이고 점진 적으로 추진해야 한다. 우선 언타이드 적용대상국 가를 최빈국 $\rightarrow$ 고채무빈곤국(Non-LDC HIPC)으 로 단계적으로 확대하는 방안을 고려해 볼 수 있 다. 2001년 DAC 최빈국 원조 언타이드 권고안 발표 이후 원조 언타이드화 대상 국가를 확대하려 는 노력이 지속되고 있으나, 회원국간 입장차이로 인하여 대상 국가 확대 결정에는 일정기간이 필요 할 것으로 예상되므로 이를 감안하여 단계적으로 대상국가로 확대하는 것이 바람직하다. 아울러 적 용 대상사업과 관련하여서는 물자지원사업의 언 타이드를 우선적으로 추진하되 프로젝트 사업의 경우에는 현지조달 여부를 고려하여 단계적으로 언타이드화를 추진할 필요가 있으며, 투자관련 기 술협력(IRTC)의 언타이드 대상화 여부도 검토해 야 한다.

이러한 대상국가 및 대상사업의 점진적 확대를 기 초로 크게 3단계로 나누어 원조 언타이드 추진계 획을 상정해볼 수 있다. 우선 준비 및 시범단계에 서는 최빈국대상 시범 사업을 통해 선별적으로 언
타이드 사업을 확대하여 언타이드 원조 비율을 20 30\% 수준으로 높일 수 있다. 그리고 DAC 가 입연도인 2010년을 목표로 무상원조 언타이드율 을 50\% 수준으로 확대하고, MDGs 실현 목표연도 인 2015년에는 언타이드율을 DAC 평균인 $90 \%$ 까 지 확대한다는 목표를 세울 수 있다.

\section{나. 제도 개선과 보안대책 마련}

원조 효과성 증대를 위한 원조 언타이드화 실시를 위해서는 조달관련 법규를 보완하고 국제입찰 및 현지조달이 원활히 추진될 수 있도록 관련 조항 수 정 및 보완이 필요하다. 언타이드 대상사업 추진과 관련하여 입찰기준을 현지입찰/국제입찰기준으로 조정하되, 언타이드 대상사업의 예외 및 세부기준 은 가능한 단순하고 명료하게 설정하여 행정비용 을 최소화해야 한다. 현지조달의 경우에는 수원국 조달체제 활용을 위한 실무적 검토가 이루어져야 하고, 현지조달 실시를 위한 가이드라인 작성이 필 요하다. 
이러한 원조 언타이드화 실시를 위한 제도 개선과 더불어 언타이드 원조 확대 추진에 따른 우리 기업 의 수주기회 축소 등 부정적 영향에 대비한 제도적 보완장치 마련이 필요하다. 원조 언타이드화를 추 진하려면 국제경쟁입찰과 현지조달시스템을 이용 해야 하기 때문에 결국 자유경쟁 원칙에 기반한 국 제조달시장에서 우리 기업의 수주율 저하를 방지 하고 진출 확대를 위한 정부적 차원에서 지원이 요 구되고 있다. 이를 위해 국제조달시장의 현황 및 우리나라의 진출현황 파악과 우리의 문제점 분석 을 통한 개선방안 모색이 필요하다.

\section{IV. 국제 원조조달시장 규모 및 우리나라 진출 현황}

\section{1. 국제 원조조달시장의 규모 확대}

국제 원조규모는 1997년 이후 지속적으로 확대되 어 왔으며 성장추세는 계속 이어질 전망이다. ODA 순집행액은 2000년 537억 달러에서 2006년 1,044 억 달러로 확대되었으며, DAC에 따르면 2010년에는 1,324억 달러(GNI 대비 0.35\%)로 증 가할 전망이다. 아울러 언타이드 원조 확대 역시 국제 원조조달시장 규모 확대 효과를 낳고 있다. 기존에 타이드화 되었던 원조조달시장의 개방으로

\section{2. 우리나라 진출 현황}

접근 가능한 국제 원조조달시장이 확대되고 있는 것이다.

국제 원조조달시장의 총규모를 명확하게 산출해내 기는 어렵지만 총 원조 규모에서 사실상 타이드화 되어 있거나 원조 언타이드화 대상에서 제외되는 분야(기술협력, 식량원조, 채무탕감, 행정비용)를 제외하면 국제원조조달시장 규모 추정이 가능하 다. 2006년의 경우, 총 ODA 규모가 1,044억 달러 이고 사실상 조달시장에서 제외되는 부분을 빼면 약 516억 달러를 원조조달시장 규모라고 볼 수 있 다. 이러한 방식으로 연도별 국제 원조조달시장 비 중을 산출해보면 2002년에서 2006년까지 총원조 의 연평균 $50.4 \%$ 의 비중을 차지하고 있음을 알 수 있다. 따라서 2010년 국제 원조조달시장의 규모는 667 억 달러로 확대될 것으로 추정해 볼 수 있다.

이처럼 국제 원조조달시장의 규모는 지속적으로 증가하고 있으나, 우리 기업의 참여는 아직까지 는 저조한 실정이다. 양자 $\mathrm{ODA}$ 사업에 대한 진출 이 활발히 이루어지고 있지 않으며, 다자 ODA 사 업을 실시하는 UN 조달시장(원조조달 포함) 및 다자개발금융기구(MDB)에서의 사업 참여도 미 미하다.

1) 유엔 조달시장은 유엔 본부를 비롯한 40개 기구의 물품 및 서비스를 조달하며, 각 기구들은 국제경쟁입찰방식 및 최적구매원칙 하에 각자의 원칙과 절차 에 따라 독립적으로 조달업무 수행함. 기관별 조달비중은 조달 금액을 기준으로 UNDP(25.4\%), UNPS(21.2\%), WFP(18.7\%), UNICEF(12.8\%), UNOPS(5.9\%)임. 
〈표 2〉〈 연도별 국제 ODA 조달시장 규모 〉

(단위: 백만 달러, \%)

\begin{tabular}{|c|c|c|c|c|c|c|c|}
\hline & $\begin{array}{l}\text { 1990-91 } \\
\text { average }\end{array}$ & $\begin{array}{l}1995-96 \\
\text { average }\end{array}$ & 2002 & 2003 & 2004 & 2005 & 2006 \\
\hline ODA(a) & 54,574 & 57,277 & 58,297 & 69,065 & 79,432 & 107,099 & 104,421 \\
\hline 1. 양자 증여 & 34,419 & 36,394 & 39,818 & 50,888 & 57,246 & 83,453 & 79,450 \\
\hline - 기술협력 & 12,023 & 14,229 & 15,452 & 18,352 & 18,672 & 20,753 & 22,252 \\
\hline - 식량원조 (b) & 1,609 & 1,087 & 1,086 & 1,196 & 1,169 & 887 & 956 \\
\hline - 인도적 원조 (b) & 1,738 & 2,153 & 2,779 & 4,360 & 5,193 & 7,110 & 6,751 \\
\hline - 채무탕감 & 5,167 & 3,561 & 4,538 & 8,317 & 7,134 & 24,999 & 18,600 \\
\hline - 행정비용 & 2,059 & 2,873 & 3,046 & 3,545 & 4,032 & 4,115 & 4,250 \\
\hline 2. 양자 차관 & 6,250 & 3,404 & 939 & $-1,153$ & $-2,942$ & $-1,008$ & $-2,490$ \\
\hline 3. 다자 원조 & 15,614 & 17,479 & 17,540 & 19,330 & 25,127 & 24,653 & 27,461 \\
\hline$-U N(c)$ & 4,351 & 4,379 & 4,739 & 4,828 & 5,129 & 5,469 & 5,239 \\
\hline$-E C(c)$ & 3,807 & 5,112 & 5,695 & 6,946 & 8,906 & 9,258 & 9,931 \\
\hline - IDA (c) & 4,467 & 4,702 & 3,279 & 3,120 & 5,690 & 4,827 & 6,787 \\
\hline - 지역개발은행(c) & 1,480 & 1,440 & 1,813 & 1,734 & 2,274 & 2,096 & 2,466 \\
\hline 조달시장규모 & 33,688 & 33,375 & 31,396 & 33,294 & 43,232 & 49,234 & 51,612 \\
\hline ODA(a) & 100 & 100 & 100 & 100 & 100 & 100 & 100 \\
\hline 1. 양자 증여 & 63.1 & 63.5 & 68.3 & 73.7 & 72.1 & 77.9 & 76.1 \\
\hline - 기술협력 & 22.0 & 24.8 & 26.5 & 26.6 & 23.5 & 19.4 & 21.3 \\
\hline - 식량원조 (b) & 2.9 & 1.9 & 1.9 & 1.7 & 1.5 & 0.8 & 0.9 \\
\hline - 인도적 원조 (b) & 3.2 & 3.8 & 4.8 & 6.3 & 6.5 & 6.6 & 6.5 \\
\hline - 채무탕감 & 9.5 & 6.2 & 7.8 & 12.0 & 9.0 & 23.3 & 17.8 \\
\hline - 행정비용 & 3.8 & 5.0 & 5.2 & 5.1 & 5.1 & 3.8 & 4.1 \\
\hline 2. 양자 차관 & 11.5 & 5.9 & 1.6 & -1.7 & -3.7 & -0.9 & -2.4 \\
\hline 3. 다자간 원조 & 28.6 & 30.5 & 30.1 & 28.0 & 31.6 & 23.0 & 26.3 \\
\hline$-\mathrm{UN}(\mathrm{c})$ & 8.0 & 7.6 & 8.1 & 7.0 & 6.5 & 5.1 & 5.0 \\
\hline$-E C(c)$ & 7.0 & 8.9 & 9.8 & 10.1 & 11.2 & 8.6 & 9.5 \\
\hline - IDA (c) & 8.2 & 8.2 & 5.6 & 4.5 & 7.2 & 4.5 & 6.5 \\
\hline - 지역개발은행 & 2.7 & 2.5 & 3.1 & 2.5 & 2.9 & 2.0 & 2.4 \\
\hline 조달시장비중(\%) & 61.7 & 58.3 & 53.9 & 48.2 & 54.4 & 46.0 & 49.4 \\
\hline
\end{tabular}

주: a) Excluding debt forgiveness of non-ODA claims in 1990 and 1991.

b) Emergency food aid included with developmental food aid up to and including 1995.

c) Grants and capital subscriptions do not include concessional lending to multilateral agencies.

d) Deflated by the total DAC deflator.

자료: DAC Members' reporting to the annual DAC Questionnaire on total official development aid 
〈표 3〉〈2005년 DAC 회원국 원조조달 계약 수주율2)〉

(단위: 백만 달러, \%)

\begin{tabular}{|c|c|c|c|c|c|c|c|c|c|c|}
\hline \multirow[t]{2}{*}{ 구분 } & \multicolumn{2}{|c|}{$\begin{array}{c}\text { DAC } \\
\text { 전체 계약 }\end{array}$} & \multicolumn{2}{|c|}{ 공여국 } & \multicolumn{2}{|c|}{$\begin{array}{c}\text { OECD내 } \\
\text { DAC 비회원국과 } \\
\text { 기타공여국 }\end{array}$} & \multicolumn{2}{|c|}{ 개도국 } & \multicolumn{2}{|c|}{ 최빈국 } \\
\hline & 건수 & 금액 & 건수 & 금액 & 건수 & 금액 & 건수 & 금액 & 건수 & 금액 \\
\hline $\mathrm{DAC}$ 합계 & 297 & 839.6 & 179 & 509.6 & 32 & 148.5 & 19 & 50.3 & 67 & 131.1 \\
\hline 2005년 수주 비율 & 100 & 100 & 60.3 & 60.7 & 10.8 & 17.7 & 6.4 & 6.0 & 22.6 & 15.6 \\
\hline
\end{tabular}

자료 : OECD/DAC Contract Award Reporting System

〈표 4〉〈우리 기업의 MDB 조달 누적 본구매 - 컨설팅 수주 현황 〉

(단위: \%)

\begin{tabular}{|c|c|c|c|c|c|}
\hline 구분 & WB(BRD/IDA) & $\mathrm{ADB}$ & IDB & EBRD & AfDB \\
\hline 본구매 & 1.20 & 2.93 & 0.00 & 0.00 & 0.51 \\
\hline 컨설팅 & 0.00 & 0.34 & 0.00 & 0.00 & - \\
\hline 기간 & '00- 07 & '03- 07 & '00-' 07 & '03-'06 & '02-' 07 \\
\hline 우리나라 지분율 & $0.99 / 0.60$ & 4.34 & 0.004 & 1.02 & 0.47 \\
\hline
\end{tabular}

자료 : Development Bank Associates, Inc.

〈표 5〉〈우리 기업의 UN 조달 시장 진출 현황〉

(단위 : 천달러)

\begin{tabular}{c|c|c|c|c|c}
\hline 구 분 & 2002 & 2003 & 2004 & 2005 & 2006 \\
\hline UN조달시장 규모 & $4,559,000$ & $5,067,000$ & $6,527,000$ & $8,331,000$ & $9,420,000$ \\
\hline 물 품 & $23,947.50$ & $19,492.63$ & $18,026.28$ & $21,538.68$ & $29,581.12$ \\
\hline 서비스 & 571.67 & 196.32 & 824,57 & $1,690.94$ & $3,137.15$ \\
\hline 우리나라 진출 합계 & 24,519 & 19,688 & 18,850 & 23,229 & 32,728 \\
\hline 우리나라 조달 비율(\%) & 0.54 & 0.39 & 0.29 & 0.28 & 0.35 \\
\hline
\end{tabular}

자료 : Annual Statistical Report 2006, UNDP/IAPSO

$\mathrm{DAC}$ 의 계약 수주 보고시스템에 따르면, 최빈국에 쟁력이 높은 선진공여국들의 원조조달시장 선점으 대한 원조 언타이드화가 권고된 이후에도 2005년 로 인해 원조 언타이드화의 확대에도 불구하고 사 $\mathrm{DAC}$ 에 보고된 회원국의 전체 계약 중에서 공여국 실상 타이드화되어 있는 국제 원조조달시장에 우 의 수주율이 금액기준 $60.7 \%$ 로 가장 높고, $\mathrm{OECD} \mathrm{리나라의} \mathrm{진출이} \mathrm{쉽지} \mathrm{않음을} \mathrm{의미한다.}$

회원국이면서 DAC 비회원국의 수주율은 금액기

준 $17.7 \%$, 개도국 $6 \%$, 최빈국 $15.6 \%$ 였다. 이는 경 $\mathrm{MDB}$ 의 경우에도 2000-2006년간 지분율 대비

2) $\mathrm{DAC}$ 전체 계약 건수 - 금액은 보고된 계약에 한함. 
조달사업 참여율이 미미하다. 세계은행(WB)의 경 우 지분율 0.99 대비 사업참여율은 $1.20 \%$ 이며, 아 시아개발은행(ADB)의 경우 지분율 4.34 대비 사 업참여율은 $2.93 \%$, 아프리카개발은행(AfDB)의 경우 지분율 4.34 대비 사업참여율은 $0.51 \%$ 이다. 그리고 미주개발은행과 유럽부흥개발은행의 경우, 지분은 보유하고 있지만 $\mathrm{ODA}$ 사업참여는 하지 못 하고 있다. UN조달시장의 경우에도 2006년 우리 나라 유엔분담금 규모는 1 억3천만 달러로 전체의 $2 \%$ 였으나, 조달시장 수주율은 $0.35 \%$ (3천만 달러) 로 분담금 대비 진출이 미미한 상황이다.

\section{V. 우리의 수주경쟁력 제고 및 컨설턴트 육성 방안}

\section{1. 우리나라 수주 부진 원인 분석}

우리나라의 경우 상대적으로 프로젝트 시공 등 하
드웨어 분야에서는 풍부한 경험과 실적을 가지고 있으나, 고부가가치 분야인 기본설계, 타당성 조사 등은 취약하다. 실제로 수주율을 높이기 위해서는 사업 발굴을 위한 타당성 조사에서의 경쟁력이 높 아야 하는데, 이를 일부 선진 공여국들이 선점하여 우리 기업들이 사업발굴단계 참여에 어려움을 겪 고 있다.

또한 우리 기업들의 수주경쟁력 향상을 위한 지원 도 미미한 상황이다. 해외사업진출이 활발한 일부 대기업을 제외한 대부분의 기업은 해외사업경험이 적고, 해외사업 수행과정에서 요구되는 언어, 서류 작성, 사업관리 능력 등을 결여하고 있어 국제원조 조달시장 접근에 어려움을 겪고 있다. 특히, 사업 발굴 단계에서 국가별, 지역별, 업종별 사전 정보 가 체계적으로 정리되어 있지 않고 이를 제공하기 위한 정보 시스템도 미비하여 기업들이 접근하여 사전 정보를 획득하는 데에 한계가 있다.

〈표 6〉〈업무단계 및 분야별 국제 경쟁력 비교(선진국=10)〉

\begin{tabular}{c|c|c|c}
\hline \multicolumn{2}{|c|}{ 업무단계별 경쟁력 } & \multicolumn{2}{c}{ 산업설비 분야별 경쟁력 } \\
\hline 기본설계 & 4.6 & 해양설비 & 6.3 \\
\hline 타당성조사 & 5.0 & 담 수 & 6.4 \\
\hline 유지· 보수 & 6.4 & 환 경 & 6.7 \\
\hline 시운전 & 6.7 & 가스처리 & 6.8 \\
\hline 구매 · 조달 & 7.1 & 일반화학 & 6.9 \\
\hline 시 공 & 7.9 & 발 전 & 7.0 \\
\hline 상세설계 & 8.2 & 석유화학 · 정유 & 7.4 \\
\hline
\end{tabular}

주: 고급기술자를 대상으로 한 설문조사결과

자료: 한국수출입은행, 『우리나라 공적개발원조의 중장기 정책방향』, 2004.7 


\section{2. 수주경쟁력 제고 방안}

국제 원조조달시장에서 우리 기업의 수주경쟁력을 제고하기 위해서는 중점원조 분야의 전환이 필요 하다. 기존 대외원조는 시공이나 물자지원 등 하드 웨어 중심으로 이루어졌으나, 실질적으로 수주율 에 영향을 미치는 개발조사사업이나 고부가가치 창출이 가능한 기술지원 등 소프트웨어 분야로의 원조 확대를 추진해야 한다. 특히, 동분야는 언타 이드 원조 대상에서도 제외됨에 주목하여 원조 언 타이드화 추진시에 전략적인 활용이 필요하다.

아울러 원조사업의 개발효과를 극대화하는 프로 젝트나 프로그램의 개발 및 사업준비와 시행을 위 해 필요한 개발 컨설팅 활성화가 긴요하다. 그러 나 현재 원조조달시장 수주율에 영향을 줄 수 있 는 원조사업 개발 및 준비를 위한 컨설팅의 경우, 특정 선진국의 개발 컨설턴트가 시장을 선점하고 있다. 따라서 우리나라 개발 컨설턴트 육성을 위 해서는 민간과의 긴밀한 협력 하에 정부적 차원에 서 컨설턴트 육성을 위한 방안 마련과 지원이 이 루어져야 한다.

국제 원조조달시장에 대한 정보 제공 및 입찰 참여 지원도 중요하다. 실제로 우리나라의 낮은 수주율 은 선진국과의 경쟁력 차이에서 기인하기도 하지 만, 원조사업 관련 정보의 사전적 확보가 어렵고 조달 입찰 관련 정보시스템의 미비로 국제 입찰에 대한 신속한 대응이 어려운 데에서도 기인한다. 또
한 언어능력 부족도 국제 원조조달시장 진출의 장 애물로 작용하고 있다. 이러한 문제를 해결하기 위 해 조달입찰 관련 정보를 신속히 제공하기 위한 정 보 시스템의 구축이 긴요하며, 실질적으로 필요한 입찰서류 작성지원 및 발주자와 협상업무 지원 등 을 위한 제도 마련이 요구된다.

\section{3. 컨설턴트 육성 방안}

선진공여국의 선점으로 사실상 타이드화되어 있는 국제 원조조달시장에서 우리의 수주 경쟁력을 높 이기 위해서 국내 컨설턴트의 경쟁력 및 역량의 강 화는 매우 중요한 정책적 과제이다. 특히, 현재 국 내 개발 컨설팅 산업 기반이 미미한 상황에서 이를 육성하기 위한 정부차원의 육성 방안 수립과 이행 이 반드시 필요하다. 이를 기반으로 민간 부문과 긴밀한 협력 하에 개발 컨설턴트 육성과 활용을 위 한 지속적인 노력이 요구된다.

우선, 정책적 차원에서는 개발컨설팅 산업 육성과 관련한 이슈에 대한 심층적 연구분석을 통해 육성 방안을 수립하고 수행해야 한다. 개발정책 지원 자 문관, 정책컨설턴트, 잠재적 개발컨설턴트 등이 참 여하고 개발컨설팅산업을 주도할 단체의 설립 지 원도 컨설턴트 육성을 촉진하는 방안이 될 수 있 다. 또한, 정책 개발사업 전문가 및 국제조달시장 관련 전문가를 발굴하여 이들을 중심으로 잠재적 개발 컨설턴트를 지원하는 기반을 구축하고 관련 전문가 육성프로그램의 설치 및 운영도 바람직하 
다. 아울러 컨설팅 $\mathrm{DB}$ 구축을 통해 전문가 풀 및 정책사례 등을 생산하여 지속적인 컨설팅 산업 육 성을 도모해야 한다. 재정적 차원에서는 국내 개발 컨설턴트 산업 기반이 매우 취약한 점을 감안하여 국내 컨설턴트들의 원조사업 참여를 유도하기 위 한 초기 진입비용 지원이 필요하다.

\section{VI. 맺음말}

언타이드 원조 확대는 이미 분명한 국제적 흐름이 며, 우리나라 역시 국제적 기준에 부합하는 원조 제공을 위해 원조 언타이드화를 추진 중에 있다. 여기서 중요한 것은 원조 언타이드화율 증대 자체 가 아니라 언타이드화를 통해서 궁극적으로 원조 효과성을 증대시킬 수 있다는 데에 있다. 이미 높 은 언타이드화율을 달성한 선진 공여국의 경우에 도 언타이드 원조 확대를 각국의 실정에 맞추어 추 진하였다. 우리나라 역시 우리나라 실정에 맞추어 원조 언타이드화를 추진해야 한다. 합리적 보완책
이 없는 성급한 언타이드화 추진은 우리 기업의 수 주기회 축소로 인해 우리의 원조정책 전반에 대한 국민적 반감을 가져올 우려가 있다.

따라서 언타이드 추진을 위한 제도적 개선과 수주 경쟁력 강화를 위한 점진적 - 단계적 언타이드화를 추진하되, 우리 기업의 확대된 국제 원조조달시장 진출을 지원하기 위한 정부적 차원에서의 방안 수 립과 이행이 이루어져야 한다. 물론, 이는 우리 기 업을 보호하기 위한 직접적 지원의 형태가 아니라 국제 원조조달시장 진출 확대를 위한 충분한 연구 와 정보제공 및 고부가가치를 창출할 수 있는 원조 사업 발굴 등 간접적 지원의 형태로 이루어져야 할 것이다. 이러한 맥락에서 개발 컨설턴트의 육성은 시급한 정책과제가 아닐 수 없다. 이러한 우리 실 정에 맞는 원조 언타이드화 추진을 통한 원조 자금 의 효과적 집행 및 원조 조달 관련 산업 육성을 통 해 국민적 지지에 기반한 원조 정책을 지속적으로 추진할 수 있을 것이라고 기대한다. 